\title{
OPTIMALISASI PERAN BMT DALAM UPAYA PENGHAPUSAN PRAKTIK RENTENIR
}

\author{
OPTIMIZING THE ROLE OF BMT IN EFFORTS TO ELIMINATE THE PRACTICE OF THE \\ MONEYLENDER \\ Visita Dwi Ayogi1aTuti Kurnia² \\ 1Program Studi Ekonomi Islam Fakultas Ekonomi Islam Universitas Djuanda, Jl. Tol Ciawi No. 1, \\ Kotak Pos 35 Bogor 16770. \\ 2 Program Studi Ekonomi Islam Fakultas Ekonomi Islam Universitas Djuanda, Jl. Tol Ciawi No. 1, \\ Kotak Pos 35 Bogor 16770
}

\begin{abstract}
The existence of the moneylender more exist until now,this is evidenced by the fact that $70 \%$ of SMEs caught on moneylenders. Such a practice is clearly to be abolished in the community because of the negative impact for the community. Therefore, the existence of Baitul Maal wa tamwil (BMT) as a microfinance institution which is operated by the Islamic principles is considered very important to eliminate the practice of moneylenders in the community. The purpose of this study was to determine the role that has been carried out by BMT in efforts to eliminate the practice of moneylenders and to determine the role played by BMT is optimal or not in efforts to eliminate the practice of moneylenders.Dataanalysistool in this study using quantitative descriptive analysis data collection through interviews.Data processing is done by using lnear programming, with the help of an application program LINDO, to complete the mathematical modeling used to optimize an objective with various constraints. Were then analyzed by analysis of primal, dual, and sensitivity.The conclusion of this study is the role performed by BMT Amal Atina and BMT Berkah Mandiri Sejahtera in efforts to eliminate the practice of the moneylender is not optimal, because the resources used to minimize the practice of excessive or moneylenders in the community still has not been used optimally.
\end{abstract}

Keywords :Role of BMT, the Moneylender.

\begin{abstract}
ABSTRAK
Keberadaan rentenir semakin eksis hingga kini, hal ini dibuktikan dengan adanya fakta bahwa 70\% UMKM terjerat pada Rentenir.Praktik seperti ini jelas harus dihapuskan di kalangan masyarakat karena menimbulkan dampak yang negatif bagi masyarakat. Oleh karena itu, keberadaan Baitul Maal wa Tamwil (BMT) sebagai lembaga keuangan mikro yang dioperasikan dengan prinsip syariah dinilai sangat penting untuk menghapuskan praktik rentenir di masyarakat. Tujuan dalam penelitian ini adalah untuk mengetahui peran yang telah dilakukan oleh BMT dalam upaya penghapusan praktik rentenir dan untuk mengetahui peran yang dilakukan oleh BMT sudah optimal atau belum dalam upaya penghapusan praktik rentenir.Alat analisis data dalam penelitian ini menggunakan analisis deskriptif kuantitatif yang pengambilan datanya melalui wawancara.Pengolahan data dilakukan dengan menggunakan linear programming, dengan bantuan program aplikasi LINDO, untuk menyelesaikan permodelan matematik yang digunakan untuk mengoptimalkan suatu tujuan dengan berbagai kendala yang ada.Yang kemudian dianalisis oleh analisis primal, dual, dan sensitivitas.Kesimpulan dalam penelitian ini adalah peran yang dilakukan oleh BMT Amal Atina dan BMT Berkah Mandiri Sejahtera dalam upaya penghapusan praktik rentenir belum dilakukan secara optimal, dikarenakan sumber daya yang digunakan untuk meminimalisir praktik rentenir dimasyarakat masih berlebih atau belum dimanfaatkan secara optimal.

Kata Kunci : Peran BMT, Rentenir.
\end{abstract}


Ayogi V D. 2014. Optimalisasi peran BMT dalam upaya penghapusan praktik rentenir. Jurnal Syarikah1(1): 1 - 18 .

\section{PENDAHULUAN}

Pada era modern ini, kebutuhan masyarakat semakin meningkat namun peningkatan kebutuhan ini tidak diiringi oleh meningkatnya pendapatan.Dengan adanya fenomena tersebut, mendorong manusia untuk melakukan sesuatu demi memenuhi kebutuhannya yang semakin lama semakin berkembang. Tingginya tingkat kebutuhan masyarakat terhadap dana atau modal, membuat masyarakat harus berhubungan dengan lembaga keuangan seperti Bank.

Namun disisi lain, para pelaku usaha kecil memiliki kendala permodalan. Para pelaku usaha kecil tidak mendapatkan akses pembiayaan di dunia perbankan, karena akses untuk mendapatkan pembiayaan ke dunia perbankan relatif sulit diberikan untuk para pelaku usaha kecil.Hal ini terjadi karena Bank Syariah masih mensyaratkan adanya jaminan dalam pengajuan pembiayaan, yang itu tidak mungkin dipenuhi oleh para pelaku usaha kecil.Selain itu, persyaratan administratif pada saat melakukan pembiayaan seperti laporan keuangan dan lainnya masih relatif sulit untuk dipenuhi oleh pelaku usaha kecil. Sedangkan pada waktu yang bersamaan para pelaku usaha kecil ini sangat membutuhkan pembiayaan untuk mencapai keinginan mereka dalam melancarkan usaha.Karena sulitnya akses untuk mendapatkan pembiayaan, tidak sedikit dari para pelaku usaha kecil berhubungan dengan rentenir.

Praktik rentenir seperti ini sangat dilarang dan diharamkan dalam ajaran Islam karena praktik ini mengandung unsur riba nasi'ah.Dimana riba nasi'ah ini riba yang muncul akibat hutang piutang.Riba nasi'ah ini mengandung sifat pemerasan terhadap golongan ekonomi lemah. Sehingga praktik ini jelas harus dihapuskan di kalangan masyarakat karena akan menimbulkan kesulitan dan kerusakan bagi masyarakat.

Munculnya lembaga keuangan BMT ini untuk memberikan alternatif kepada masyarakat kalangan bawah dalam mendapatkan pembiayaan dengan kewajiban pengembalian yang cukup ringan.Sehingga masyarakat tidak harus meminjam kepada rentenir lagi.Dengan adanya peran BMT dalam memberikan pembiayaan dengan akses yang mudah ini diharapkan bisa menghapuskan praktik rentenir di masyarakat.Namun kenyataannya, rentenir masih tetap diminati oleh para pelaku usaha kecil hingga saat ini.Hal ini terbukti dengan adanya fakta bahwa 70\% UMKM terjerat pada rentenir di Jawa Barat.

\section{MATERI DAN METODE}

Penelitian ini adalah penelitian deskriptif kuantitatif yang berupaya mengungkapkan peranan BMT serta keoptimalan peran BMT yang dilakukan oleh BMT Amal Atina dan BMT Berkah Mandiri Sejahtera dalam upaya menghapuskan praktik rentenir di masyarakat. Teknik pengumpulan data dalam penelitian ini melalui teknik wawancara atau interview secara langsung dengan nasabah BMT yang dulunya menggunakan jasa Rentenir, dan pihak BMT. Serta melalui dokumentasi mengenai jumlah nasabah yang memanfaatkan jasa BMT Amal Atina dan BMT Berkah Mandiri Sejahtera, jumlah nasabah BMT Amal Atina dan BMT Berkah Mandiri Sejahtera yang dulunya pernah menggunakan jasa Rentenir serta jumlah masyarakat yang terkena Rentenir.

Metode pengolahan data dan analisis data dilakukan dengan menggunakan linear programming yang merupakan suatu teknik optimalisasi dimana variabelvariabelnya linier. Dengan menggunakan 
software LINDO (Linear Interactive and Discrete Optimizer) dalam pengolahan data pada penelitian ini. Data-data yang telah diolah dan analisis tersebut digunakan untuk memberikan alternatif model yang tepat untuk diterapkan oleh BMT sesuai dengan kondisi BMT tersebut.

1. Menentukan Variabel Keputusan

Variabel keputusan menunjukan keputusan yang akan diambil terkait dengan jumlah dan variabel apa yang akan diteliti. Oleh karena itu dalam model Linear Programming yang akan disusun, diperoleh dua variabel keputusan di BMT Amal Atina selama periode (dua tahun) operasional yaitu periode tahun 2012 dan tahun 2013. Variabel keputusan disimbolkan dengan $\mathrm{X}_{\mathrm{i}}$ (i menunjukan desa yang telah diberdayakan oleh BMT),dimana pada BMT Amal Atina variabel keputusannya adalah :

$$
\begin{aligned}
& \mathrm{X}_{1}=\text { Desa Cikeas } \\
& \mathrm{X}_{2}=\text { Desa Sukaraja }
\end{aligned}
$$

Sedangkan pada BMT Berkah Mandiri Sejahtera variabel keputusannya adalah :

$$
\begin{aligned}
& X_{1}=\text { Desa Citeko } \\
& X_{2}=\text { Kelurahan Sindangsari }
\end{aligned}
$$

\section{Tabel 1. Peubah Keputusan} Langkah -Langkah :

Keterangan :

$$
\text { Meminimumkan : } \mathrm{Z}=\sum \mathrm{C}_{\mathrm{ij}} \mathrm{X}_{\mathrm{ij}}
$$

$\mathrm{Z}=$ Nilai fungsi tujuan / minimalisasi nasabah yang menggunakan jasa Rentenir

$\mathrm{C}_{\mathrm{ij}}=$ Koefisien $\mathrm{X}_{\mathrm{j}}$ pada $\mathrm{Z}$

$\mathrm{X}_{\mathrm{ij}}=$ Variabel keputusan

\section{Menentukan Kendala}

Dalam proses mengoptimalkan peran BMT, BMT dihadapi dengan segala macam keterbatasan. Keterbatasan inilah yang kemudian dijadikan kendala-kendala yang dihadapi BMT.Kendala tersebut terkait dengan ketersediaan modal BMT, jumlah tenaga kerja BMT, kurangnya sosialisasi, sera jumlah biaya transportasi dalam operasional BMT.

Formulasi model yang dapat dibentuk adalah :

a. Kendala modal BMT

Fungsi :

$$
\sum m_{i j} X_{i j} \leq M_{i j}
$$

Dimana :

$\mathrm{m}_{\mathrm{ij}}=$ Koefisien modal BMT Amal Atina yang digunakan pada setiap variabel keputusan dalam periode ke-j.

$\mathrm{M}_{\mathrm{ij}}$ =Ketersediaan modal BMT Amal Atina (Rupiah/tahun)

b. Kendala SDM BMT

Fungsi :

Dimana :

$$
\sum \mathrm{d}_{\mathrm{ij}} \mathrm{X}_{\mathrm{ij}} \leq \mathrm{D}_{\mathrm{ij}}
$$

$\mathrm{d}_{\mathrm{ij}}=$ Koefisien SDM pada BMT Amal Atina periode ke-j.

$\mathrm{D}_{\mathrm{ij}}=$ Ketersediaan SDM pada BMT Amal Atina (orang).

c. Kendala sosialisasi

Fungsi :

Dimana :

$$
\sum \mathrm{S}_{\mathrm{ij}} \mathrm{X}_{\mathrm{ij}} \leq \mathrm{S}_{\mathrm{ij}}
$$

peran yang dilakukan oleh BMT adalah untuk meminimalisir jumlah nasabah yang menggunakan jasa Rentenir.Perumusan fungsi tujuan dimulai dengan menentukan jumlah nasabah yang menggunakan jasa Rentenir sebagai koefisien, selanjutnya dibentuk persamaan tujuan dalam modal linier. Formulasi persamaan fungsi tujuan yang diperoleh yaitu : $\mathrm{s}_{\mathrm{ij}}=$ Koefisien sosialisasi pada BMT Amal Atina dalam periode ke-j.

$S_{\mathrm{ij}}=$ Ketersediaan sosialisasi pada BMT Amal Atina

d. Kendala dalam jangkauan BMT

Fungsi :

$$
\sum t_{i j} X_{i j} \leq T_{i j}
$$

Dimana : 
$t_{i j}=$ Koefisien jangkaun pada BMT Amal Atina dalam periode ke-j.

$\mathrm{T}_{\mathrm{ij}}=$ Ketersediaan jangkauan pada BMT

Analisis data dilakukansetelah data diolah dan diformulasikan ke dalam model linear programmingyang ditampilkan dalam bentuk tabel.Tujuan dari analisis data ini untuk menyederhanakan data dalam bentuk yang lebih mudah dibaca dan diinterprestasikan. Analisis yang akan dilakukan dari hasil olahan LINDO meliputi:

1. Analisis Primal yang bertujuan untuk membandingkan hasil peran yang optimal dan peran yang aktual untuk mengetahui peran BMT sudah optimal atau belum.

2. Analisis Dual yang bertujuan untuk mengetahui penilaian terhadap sumber daya dengan melihat slack/surplus dari nilai dual yang dihasilkan.

3. Analisis Sensitivitas yang menunjukkan batas maksimum dan batas minimum nilai koefisien fungsi tujuan dan nilai ruas kanan kendala pada hasil optimalisasi peran.

\section{HASIL DAN PEMBAHASAN}

Salah satu peran yang harus dijalankan oleh BMT adalah menghapuskan praktik ribawi yang ada di masyarakat. Dalam menjalankan perananya itu, BMT Amal Atina an BMT Berkah Mandiri Sejahtera telah melakukan upaya-upaya untuk membebaskan masyarakat dari praktik Rentenir, diantaranya:

\section{BMT Amal Atina}

a. Penyampaian program ekonomi syariah melalui sosialisasi

Upaya BMT Amal Atina yang pertama dilakukan dalam membebaskan praktik Rentenir adalah sosialisasi kepada masyarakat secara langsung.Sosialisasi yangh dilakukan adalah dengan memberi penyuluhan dan pemahaman tentang BMT serta bahayanya praktik Rentenir di masyarakat.Sosialisasi secara formal ini dilakukan pada tahun 2010. Dan pada tahun tersebut masyarakat mulai merasakan manfaat BMT, namun sejak tahun 2012 sampai saat ini BMT dimasyarakat sudah mulai pudar akibat tidak adanya sosialisasi secara formal yang dilakukan oleh BMT Amal Atina.

Sosialisasi yang dilakukan pada tahun 2012 sampai tahun ini hanya sebatas memberikan brosur dan turun langsung ke lapangan namun tidak secara formal. Oleh karenanya, pimpinan BMT Amal Atina juga mengakui bahwa tahun ini tidak optimal dalam melakukan sosialisasi kepada masyarakat, tidak seperti tahun 2010 yang aktif memberikan sosialisasi kepada masyarakat melalui majlis-majlis atau perorangan. Bahkan pada tahun 2010, BMT sampai mendatangi pertokoan untuk bersosialisasi.
b. Memberikan model pembiayaan secara syariah

Upaya yang dilakukan BMT untuk membebaskan masyarakat dari rentenir adalah dalam bentuk pemberian pembiayaan secara syariah.Artinya dalam memberikan pembiayaan kepada nasabah harus yang sesuai syariah, misalnya dengan memberikan pembiayaan tanpa memberikan bunga kepada nasabah yang bersifat mendzalimi nasabah dan menggunakan akad-akad yang ada dalam syariah.

Hal ini bertujuan memberikan pemahaman kepada masyarakat bahwa pembiayaan dalam syariah tidak bersifat mendzalimi, karena sistem yang dipakai adalah sistem bagi hasil bukan sistem bunga. Sistem itu berjalan dengan sifat suka sama suka (antar wa diminkum). Jadi, tidak ada unsur mendzalimi terhadap sesama.

c. Membentuk gerakan BMT melalui Majelis Keluarga Utama

Upaya selanjutnya yang dilakukan oleh BMT Amal Atina adalah membentuk Majelis Keluarga Utama.Tujuan dibentuknya majelis ini guna menghimbau masyarakat yang sudah berkeluarga jika ada kesulitan dalam memenuhi kebutuhan keluarga tidak meminjam kepada 
Rentenir, karena itu bukan menyelesaikan masalah namun semakin menambah masalah, karena sistem yang dipakai oleh Rentenir adalah sistem bunga berbunga. Jadi, jika si peminjam tidak bisa membayar maka bunganya akan semakin bertambah.

Di sisi lain, banyak kasus di masyarakat yang meminjam kepada Rentenir namun tidak bilang terlebih dahulu kepada keluarga. Jadi, peminjam sembunyi-sembunyi jika ingin meminjam kepada Rentenir.Hal itu pula yang melatarbelakangi dibentuknya Majelis Keluarga Utama ini.

\section{BMT Berkah Mandiri Sejahtera}

a. Pendekatan dengan nilai-nilai akidah dan akhlak

Upaya pertama yang dilakukan oleh BMT untuk membebaskan masyarakat dari praktik Rentenir adalah dalam bentuk pendekatan nilai-nilai akidah dan akhlak kepada masyarakat. Hal ini dilakukan karena akidah yang saat ini dijalankan oleh masyarakat sudah menyatu dengan budaya yang ada.Padahal akidah itu tidak bisa disamakan dengan budaya.Oleh karena itu, BMT Berkah Mandiri Sejahtera melakukan pendekatan kepada masyarakat terkait nilai-nilai akidah agar nilai-nilai akidah yang berjalan di masyarakat menjadi benar.

BMT beranggapan jika nilai-nilai akidah di masyarakat sudah diterapkan dengan benar maka masyarakat pun dengan sendirinya akan meninggalkan praktik ribawi yang sudah lama berjalan di masyarakat. Pendekatan ini bisa dilakukan melalui sosialisasi atau melalui kunjungan ke masyarakat langsung.

b. Pendekatan dengan tokoh masyarakat

Upaya yang dilakukan selanjutnya adalah pendekatan kepada tokoh-tokoh masyarakat, seperti ulama-ulama yang ada di lingkungan masyarakat. Hal ini dilakukan karena BMT beranggapan bahwa masyarakat saat ini masih sangat mempercayai dan menghormati ulamaulama yang ada di lingkungannya.Karena ulama-ulama tersebut sebagai panutan masyarakat.

Oleh karena itu, jika ulama-ulamanya sudah benar-benar paham oleh adanya larangan praktik riba dalam Islam, maka secara tidak langsung BMT juga sedang memberi pemahaman kepada masyarakat, karena ulama-ulama tersebut pasti akan menyampaikan lagi kepada masyarakatnya. Pendekatan seperti ini lebih efisien untuk dilakukan oleh BMT lain.
c. Memberikan kemudahan dalam memberikan pembiayaan kepada masyarakat

Keunggulan praktik Rentenir adalah prosedur yang mudah dan simple dalam mendapatkan pembiayaan, karena hanya dengan mem-fotocopy KTP mereka dan menunggu satu sampai dua hari mereka sudah bisa memperoleh pembiayaan. Hal inilah yang membuat masyarakat lebih memilih meminjam ke Rentenir dibandingkan BMT. Karena anggapan masyarakat BMT itu sama saja halnya dengan Bank yang memiliki banyak prosedur dan lama dalam pengajuan pembiyaan.

Oleh karena itu, salah satu upaya BMT sebagai kompetitor dari Rentenir adalah dengan cara memperbaiki prosedur dalam pengajuan pembiayaan agar lebih mudah dan cepat seperti yang diinginkan oleh nasabah, namun tetap memperhatikan prinsip kehati-hatian.

d. Memperbanyak kelompok-kelompok muamalah atau jama'ah di komunitas pedagang

Upaya selanjutnya yang dilakukan oleh BMT adalah memperbanyak kelompok-kelompok muamalah atau jama'ah di komunitas pedagang atau kelompok lain. Hal ini bertujuan agar mempermudah BMT dalam melakukan sosialisasi ke masyarakat dan pembinaan mengenai transaksi-transaksi yang sesuai syariah.

Kelompok ini terdiri dari beberapa orang yang merupakan pedagang dari berbagai desa lalu disatukan untuk 
dijadikan kelompok.Kelompok ini nantinya juga bisa sharing kepada BMT terkait permasalahan-permasalahan yang sedang terjadi di masyarakat sekaligus mencari solusi pada permasalahan tersebut.Dengan adanya kelompok ini, BMT jadi bisa melakukan sosialisasi secara kontinue kepada masyarakat mengenai muamalah.

1. BMT Amal Atina

Berdasarkan hasil penelitian di lapangan menyatakan bahwa jumlah masyarakat yang menggunakan jasa rentenir masih banyak. Ini terbukti bahwa berdasarkan hasil wawancara dengan pihak desa menunjukkan jumlah masyarakat yang menggunakan jasa rentenir di desa Cikeas dan Sukaraja pada tahun 2012 berjumlah 200 dan 107 orang. Namun angka ini mengalami penurunan pada tahun berikutnya yakni pada tahun 2013 menjadi berjumlah 150 orang pada desa Cikeas dan 64 orang pada desa Sukaraja.

Tabel 2.Jumlah masyarakat yang menggunakan jasa rentenir pada desa Cikeas dan Sukaraja

\begin{tabular}{ccc}
\hline Periode & $\begin{array}{c}\text { sa/Kelurahan } \\
\text { Cikeas }\end{array}$ & Sukaraja \\
\hline 2012 & 200 & 107 \\
2013 & 150 & 64 \\
\hline
\end{tabular}

Sumber : BMT Amal Atina, Desa Cikeas, Kelurahan Sukaraja (2014)

Setelah jumlah masyarakat yang menggunakan jasa rentenir pada desa Cikeas dan Sukaraja diketahui, maka fungsi tujuan dapat dirumuskan sebagai berikut :

MIN Z : $200 \mathrm{X}_{11}+150 \mathrm{X}_{12}+107 \mathrm{X}_{21}+64 \mathrm{X}_{22}$

Dengan formulasi kendala yang dapat dibentuk adalah :

Kendala modal BMT

Formulasi Kendala Modal BMT

- 95.359.327X $\mathrm{X}_{11}+84.321 .622 \mathrm{X}_{12} \leq$ 141.856 .841
- $\quad$ 186.177.734 $\mathrm{X}_{21}+164.627 .929 \mathrm{X}_{22}$ $\leq 141.856 .841$

Kendala SDM BMT

Formulasi Kendala SDM BMT

$1 \mathrm{X}_{11}+1 \mathrm{X}_{12} \leq 4$

$1 X_{21}+1 X_{22} \leq 4$

Kendala sosialisasi

Formulasi Kendala Sosialisasi BMT

$0 \mathrm{X}_{11}+0 \mathrm{X}_{12} \leq 0$

$0 \mathrm{X}_{21}+0 \mathrm{X}_{22} \leq 0$

Kendala dalam jangkauan BMT

Formulasi Kendala Jangkauan BMT

- $3.120 .000 \mathrm{X}_{11}+3.120 .000 \mathrm{X}_{12} \leq$ 12.480 .000

- $3.120 .000 \mathrm{X}_{21}+3.120 .000 \mathrm{X}_{22} \leq$ 12.480 .000

Hasil optimalisasi fungsi tujuan :

Tabel 3. Tingkat jumlah masyarakat yang menggunakan jasa Rentenir di setiap Desa dalam kondisi aktual dan optimal

\begin{tabular}{ccccc}
\hline Periode & \multicolumn{2}{c}{ Desa Cikeas } \\
& Var & $\begin{array}{c}\text { Aktual)ptimal } \\
\text { (orang) }\end{array}$ & $\begin{array}{c}\text { jelisih } \\
\text { orang) }\end{array}$ \\
\hline 2012 & $S_{11}$ & 200 & 0 & 200 \\
2013 & $S_{12}$ & 150 & 0 & 150 \\
& Desa Sukaraja & \\
Periode & \multicolumn{5}{c}{ Aktual } & Jptimal & jelisih \\
& Var & orang) & (orang) & orang) \\
2012 & $S_{21}$ & 107 & 0 & 107 \\
2013 & $S_{22}$ & 64 & 0 & 64 \\
\hline
\end{tabular}

Sumber : BMT Amal Atina, Desa Cikeas, Kelurahan Sukaraja (2014)

Berdasarkan Tabel diatas, dapat diamati bahwa kondisi aktual jumlah masyarakat yang menggunakan jasa Rentenir di setiap desa selalu berubahubah dan menunjukkan bahwa setiap tahunnya mengalami penurunan. Perbedaan kondisi seperti ini terjadi disebabkan salah satu faktornya adalah masyarakat sudah mulai paham dan sadar akan dampak Rentenir yang sangat berbahaya dan di desa juga sudah mulai banyak koperasi yang masuk, serta sudah ada dukungan pula dari Pemerintah melalui bantuan dana yang diberikan ke 
setiap desa berupa dana untuk masyarakat yang membutuhkan modal guna pengembangan usaha yakni program PNPM.

Setiap desa secara keseluruhan terdapat nilai reduced cost pada peubah $\mathrm{X}_{11}, \mathrm{X}_{12}, \mathrm{X}_{21}$, dan $\mathrm{X}_{22}$ hal ini menunjukkan bahwaBMT Amal Atina dianjurkan bahwa kinerja BMT harus lebih ditingkatkan lagi karena jika tidak ditingkatkan maka tingkat masyarakat yang menggunakan jasa Rentenir tidak akan berkurang.

Dalam hal ini, analisis dual memberikan penilaian terhadap sumber daya dengan melihat nilai slack/surplus dan nilai dual price. Slack/surplus sama dengan nol menunjukan bahwa sumber daya bersifat terbatas atau langka yang termasuk dalam sumber daya aktif. Nilai dual price merupakan nilai harga sumber daya yang menunjukkan besarnya pengaruh terhadap nilai fungsi tujuan, karena penambahan atau pengurangan pada nilai ruas kanan kendala.

Nilai dual price pada sumber daya terbatas menunjukkan bahwa setiap penambahan sumber daya sebesar satusatuan akan meningkatkan nilai fungsi tujuan sebesar nilai dual pricenya, sedangkan nilai dual price negatif pada sumber daya terbatas menunjukkan bahwa setiap penambahan sumber daya sebesar satu-satuan akan menurunkan nilai fungsi tujuan sebesar nilai dual price tersebut. Sumber daya dengan nilai dual price sama dengan nol menunjukkan bahwa sumber daya tersebut berstatus kendala tidak aktif atau berlebih, dimana penambahan atau pengurangan ketersediaan pada sumber daya tersebut tidak akan mempengaruhi nilai pada fungsi tujuan.

1) Penggunaan modal BMT

Penggunaan modal BMT Amal Atina selama 2 periode (tahun 2012 dan 2013) pada kondisi optimal dapat dilihat pada tabel.Status penggunaan modal BMT Amal Atina secara keseluruhan berstatus berlebih.Hal ini menunjukkan bahwa penggunaan ketersediaan modal BMT
Amal Atina belum dimanfaatkan sepenuhnyauntuk penghapusan praktik rentenir. Artinya, BMT Amal Atina belum memberikan pembiayaan yang optimal kepada desa Cikeas dan desa Sukaraja, karena berdasarkan data penelitian masih sedikit pembiayaan yang diberikan kepada desa Cikeas dan desa Sukaraja sedangkan jumlah masyarakat yang menggunakan jasa rentenir masih banyak. Seharusnya pembiayaan BMT Amal Atina lebih diperbesar lagi untuk desa Cikeas dan desa Sukaraja ataupun pada desa-desa yang masyarakatnya masih banyak menggunakan jasa rentenir sehingga masyarakat yang masih menggunakan jasa rentenir menjadi beralih ke BMT Amal Atina. Untuk itu, meskipun ketersediaan modal BMT Amal Atina ditambah, jumlah nasabah Rentenir tidak akan berubah menjadi berkurang, karena nilai dual pricenya sama dengan 0 .

Tabel 4. Hasil Optimalisasi Penggunaan Modal BMT

\begin{tabular}{ccrc}
\hline Periode & $\begin{array}{c}\text { Slack } \\
\text { / Surplus }\end{array}$ & $\begin{array}{r}\text { Dual } \\
\text { Price }\end{array}$ & Status \\
\hline 2012 & 141856848.0 & 0.0 & Berlebih \\
2013 & 141856848.0 & 0.0 & Berlebih \\
\hline
\end{tabular}

\section{1) Penggunaan SDM BMT}

Faktor yang menyerap biaya besar pada BMT salah satunya adalah Sumber Daya Manusia.Penggunaan SDM pada BMT secara keseluruhan juga berstatus berebih. Hal ini menunjukkan bahwa ketersediaan SDM masih belum dimanfaatkan sepenuhnyauntuk mengupayakan penghapusan praktik rentenir di masyarakat.. Untuk itu, ketersediaan SDM tidak perlu ditambah, karena dengan SDM yang berjumlah saat ini masih bisa meminimalisir jumlah praktik Rentenir di masyarakat. Seharusnya kinerja SDM yang perlu ditambah dan menyusun strategi yang baik agar bisa meningkatkan jumlah nasabah BMT Amal Atina, dengan hal itu masyarakat yang pernah menggunakan jasa rentenir jadi berpindah ke BMT Amal Atina dan hal tersebut bisa mengurangi 
atau meminimalisir jumlah praktik rentenir di masyarakat.

Tabel 5. Hasil Optimalisasi Penggunaan SDM BMT

\begin{tabular}{rrrl}
\hline Periode & $\begin{array}{r}\text { Slack / } \\
\text { Surplus }\end{array}$ & $\begin{array}{r}\text { Dual } \\
\text { Price }\end{array}$ & Status \\
\hline 2012 & 4.0 & 0.0 & Berlebih \\
2013 & 4.0 & 0.0 & Berlebih \\
\hline
\end{tabular}

1) Penggunaan sosialisasi BMT

Sosialisasi yang dilakukan BMT Amal Atina memang belum optimal pada tahun 2012 dan 2013. Hal ini diakui oleh pimpinan BMT Amal Atina yang menjelaskan bahwa tahun 2012 dan 2013 memang tidak melakukan sosialisasi secara formal kepada masyarakat. Sosialisasi secara formal telah dilakukan oleh BMT Amal Atina pada tahun 2010, sedangkan pada tahun 2011, 2012, dan 2013 tidak dilakukan sosialisasi kembali dikarenakan dengan adanya sosialisasi pada tahun 2010, masyarakat sudah paham akan ekonomi syariah, BMT, dan bahaya meminjam ke rentenir. Dan masyarakat menjadi kenal dengan BMT Amal Atina(Hidayat Kahadean:2014).

Jadi, menurut BMT Amal Atina tidak perlu dilakukan sosialisasi secara formal, dikarenakan sosialisasi secara formal akan membutuhkan biaya dan SDM yang tidak sedikit. Hal tersebut akan membuat pengeluaran BMT semakin besar. Menurut BMT Amal Atina, sosialisasi juga dapat dilakukan oleh staff kredit yang setiap harinya turun ke lapangan untuk menemui nasabah.

Tabel 6. Hasil Optimalisasi Penggunaan Sosialisasi BMT

\section{2) Penggunaan jangkauan BMT}

Dalam menjalankan operasionalnya, BMT Amal Atina menggunakan metode jemput bola.Metode ini menyerap biaya besar karena jangkauan BMT Amal Atina sangat luas. Namun dalam penggunaan biaya transportasi BMT Amal Atina pada desa Cikeas dan Desa Sukaraja masih berstatus berlebih, artinya ketersediaan biaya transportasi untuk desa Cikeas dan Desa Sukaraja masih belum dimanfaatkan sepenuhnya dalam mengupayakan penghapusan praktik rentenir di masyarakat. Untuk itu, ketersediaan biaya transportasi tidak usah ditambah, karena nilai dual price nya secara keseluruhan masih bernilai 0. Seharusnya BMT Amal Atina meningkatkan kinerja SDM BMT Amal Atina agar mendapatkan nasabah yang lebih banyak pada desa Cikeas dan desa Sukaraja, sehingga masyarakat yang masih menggunakan jasa rentenir menjadi beralih menggunakan jasa BMT Amal Atina yang kemudian biaya transportasi bisa dimanfaatkan sepenuhnya untuk metode jemput bola pada desa Cikeas dan desa Sukaraja.

\section{Analisis Sensitivitas}

Analisis sensitivitas diperlukan untuk mengetahui sejauh mana hasil optimal dapat diterapkan apabila terjadi perubahan terhadap model.Pengaruh perubahan dapat dilihat dari selang kepekaan yang terdiri dari batas minimum dan batasan maksimum.Batas minimum (allowable decrease) merupakan batas penurunan kendala yang tidak merubah model dan batas maksimum (allowable increase) merupakan batas kenaikan kendala yang tidak merubah model. Semakin sempit selang kepekaan yang dimiliki oleh suatu kendala, maka kendala tersebut akan semakin peka dalam membuat perubahan terhadap solusi optimal. Analisis sensitivitas terbagi menjadi dua, yaitu analisis sensitivitas nilai koefisien fungsi tujuan dan analisis sensitivitas ruas kanan kendala.

\begin{tabular}{rrrl} 
Periode & $\begin{array}{r}\text { Slack / } \\
\text { Surplus }\end{array}$ & $\begin{array}{r}\text { Dual } \\
\text { Price }\end{array}$ & Status \\
\hline 2012 & 0.000000 & 0.000000 & Berlebih \\
2013 & 0.000000 & 0.000000 & Berlebih \\
\hline
\end{tabular}


Analisis sensitivitas nilai koefisien fungsi tujuan

Analisis sensitivitas nilai koefisien fungsi tujuan merupakan selang perubahan harga terhadap koefisien fungsi tujuan yang tidak mempengaruhi nilai optimal dari peubah, walaupun nilai optimum akan berubah sesuai dengan perubahan harga pada masing-masing peubah tersebut.

Tabel 7. Analisis Sensitivitas Nilai Koefisien Fungsi Tujuan

\begin{tabular}{lccl}
\hline eubah & $\begin{array}{r}\text { Current } \\
\text { Coef. }\end{array}$ & $\begin{array}{r}\text { Allowable } \\
\text { Increase }\end{array}$ & $\begin{array}{c}\text { Allowable } \\
\text { Decrease }\end{array}$ \\
\hline $\mathrm{X} 11$ & 200.00 & INFINITY & 200.0 \\
$\mathrm{X} 12$ & 150.00 & INFINITY & 150.0 \\
$\mathrm{X} 21$ & 107.00 & INFINITY & 107.0 \\
$\mathrm{X} 22$ & 64.00 & INFINITY & 64.0 \\
\hline
\end{tabular}

\begin{tabular}{lrrc} 
Row & $\begin{array}{r}\text { Current } \\
\text { RHS }\end{array}$ & $\begin{array}{r}\text { Allow } \\
\text { able } \\
\text { Increa } \\
\text { se }\end{array}$ & $\begin{array}{c}\text { Allow } \\
\text { able } \\
\text { Decrea } \\
\text { se }\end{array}$ \\
\hline M01 & 41856848 & NFINITY & 1856848 \\
M02 & 41856848 & NFINITY & 1856848 \\
\hline
\end{tabular}

Berdasarkan tabel diatas, dapat dilihat banyak peubah yang tidak memiliki batasan (infinity) dalam menaikan koefisien fungsi tujuan, akan tetapi memiliki batasan dalam menurunkan koefisien fungsi tujuannya. Nilai masingmasing batasan berbeda untuk setiap peubah. Sebagai contoh, peubah $\mathrm{X}_{11}$

tidak memiliki batasan dalam menaikkan koefisiennya dan memiliki batasan dalam menurunkan koefisien sejumlah 200 orang.

\section{- Analisis sensitivitas nilai ruas kanan kendala}

Analisis sensitivitas nilai ruas kanan kendala menunjukkan selang perubahan pada ketersediaan sumber daya yang tidak akan menyebabkan nilai dual berubah. Semakin sempit selang kepekaan suatu sumber daya, berarti sumber daya tersebut semakin peka terhadap perubahan nilai ruas kanan kendalanya.Batas perubahan yang terjadi pada kendala-kendala yang menjadi pembatas peran BMT setiap periodenya.Untuk kendala-kendala yang berstatus berlebih, pada analisis sensitivitas nilai ruas kanan kendala memiliki nilai peningkatan yang tak terbatas.Sedangkan untuk kendalakendala yang berstatus langka memiliki nilai batas penggunaan untuk penambahan atau pengurangan sumber daya sampai batas tertentu.Selang kepekaan ketersediaan modal dapat dilihat pada tabel dibawah ini.Pada kolom (1), menunjukkan kendala modal dimulai dari M01-M02.Kolom (2), menunjukkan ketersediaan modal BMT.Sedangkan kolom (3) dan (4), menunjukkan selang dari ketersediaan modal yang dapat diterima model.Untuk ketersediaan modal, batasan kenaikan (allowable increase) yang dapat diterima model menunjukkan batas tak hingga dan batas berhingga.

Batas tak hingga berarti persediaan modal berlebih.Sedangkan batas berhingga menunjukkan adanya batas peningkatan sampai nilai tertentu (sesuai nilai pada tabel).Berdasarkan Tabel diatas, menunjukkan bahwa terdapat batas peningkatan tak hingga pada model. Untuk itu tidak ada gunanya menambah penggunaan modal, karena sebenarnya modal untuk mengatasi masyarakat yang menggunakan jasa Rentenir masih berlebih, artinya banyak modal yang belum dialokasikan untuk menangani masyarakat yang menggunakan jasa Rentenir agar minimalisasi praktik Rentenir di masyarakat bisa tercapai. Batasan pengurangan penggunaan modal sebesar Rp. 181.856.848.

Tabel 8.Selang kepekaan ketersediaan

\begin{tabular}{rrrr}
\hline Row & $\begin{array}{r}\text { Current } \\
\text { RHS }\end{array}$ & $\begin{array}{l}\text { lowable } \\
\text { Increase }\end{array}$ & $\begin{array}{r}\text { llowable } \\
\text { Decrease }\end{array}$ \\
\hline D01 & $: .000000$ & NFINITY & 4.00 \\
D02 & .000000 & NFINITY & 4.00 \\
\hline \multicolumn{3}{c}{ SDM BMT } &
\end{tabular}


Berdasarkan Tabel diatas, menunjukkan bahwa terdapat batas peningkatan tak hingga pada model. Untuk itu tidak ada gunanya menambah penggunaan SDM pada BMT dalam meminimalisir praktik Rentenir di masyarakat, karena sebenarnya SDM yang ada pada BMT saat ini mengalami kelebihan, artinya SDM BMT belum memanfaatkan secara optimal dalam menjalankan perannya sebagai penghapus praktik ribawi di masyarakat. Dengan jumlah SDM BMT saat ini, BMT masih bisa mengatasi atau berperan dalam meminimalisir praktik Rentenir di masyarakat.Batasan pengurangan penggunaan SDM sebesar 4 Orang.

Tabel 9.Selang kepekaan ketersediaan sosialisasi BMT

\begin{tabular}{rrrr}
\hline Row & $\begin{array}{r}\text { Current } \\
\text { RHS }\end{array}$ & $\begin{array}{r}\text { Allowable } \\
\text { Increase }\end{array}$ & $\begin{array}{r}\text { Allowable } \\
\text { Decrease }\end{array}$ \\
\hline S01 & 0.000000 & INFINITY & 0.000000 \\
S02 & 0.000000 & INFINITY & 0.000000 \\
\hline
\end{tabular}

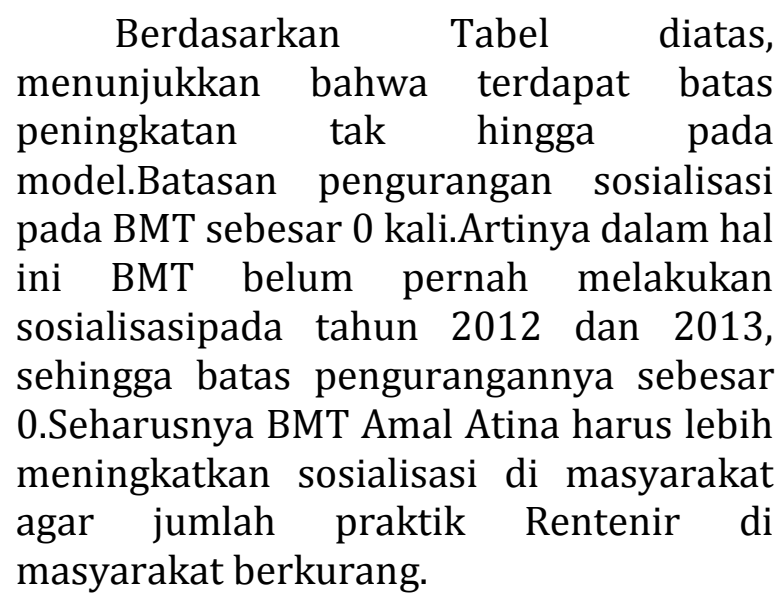

Tabel10. Selang kepekaan ketersediaan jangkauan BMT

\begin{tabular}{llcc}
\hline Row & $\begin{array}{l}\text { Current } \\
\text { RHS }\end{array}$ & $\begin{array}{c}\text { Allowable } \\
\text { Increase }\end{array}$ & $\begin{array}{c}\text { Allowable } \\
\text { Decrease }\end{array}$ \\
\hline P01 & 12480000 & INFINITY & 12480000 \\
P02 & 12480000 & INFINITY & 12480000 \\
\hline
\end{tabular}

Berdasarkan Tabel diatas, menunjukkan bahwa terdapat batas peningkatan tak hingga pada model. Untuk itu tidak ada gunanya menambah biaya transportasi, karena sebenarnya biaya transportasi mengalami kelebihan, artinya BMT harus menambah kinerjaagar nasabah BMT banyak dan jumlah praktik Rentenir akan berkurang dan pemakaian biaya transportasi menjadi banyak yang dimanfaatkan. Batasan pengurangan penggunaan biaya transportasi sebesar Rp. 12.480.000.

3. BMT Berkah Mandiri Sejahtera

Berdasarkan hasil penelitian di lapangan menyatakan bahwa jumlah masyarakat yang menggunakan jasa rentenir masih banyak. Ini terbukti bahwa berdasarkan hasil wawancara dengan pihak desa menunjukkan jumlah masyarakat yang menggunakan jasa rentenir di desa Citeko dan Kelurahan Sindangsari pada tahun 2013 berjumlah 200 dan 192 orang. Hasil ini diperoleh dari hasil wawancara penulis dengan salah satu aparat desa di desa Citeko, yakni ketua RW 02.Menurut bapak Lukman menyebutkan bahwa warganya masih banyak yang menggunakan jasa rentenir. Menurutnya ada sekitar 20 warganya yang masih menggunakan jasarentenir, jika dirata-ratakan setiap RW pada desa Citeko berjumlah 20 orang, maka didapatkan hasil 200 orang.

Sedangkan di kelurahan Sindangsari pun masih banyak jumlah masyarakat yang menggunakan jasa rentenir. Berdasarkan hasil wawancara dengan salah satu warga kelurahan Sindangsari yakni bapak Asep Junjunan menyebutkan bahwa sekitar 6 orang pada RT 05 masih menggunakan jasa rentenir, jika dirataratakan setiap RT pada kelurahan Sindangsari berjumlah 6 orang, maka didapat hasil 192 orang(Junjunan:2014).

Namun angka ini mengalami penurunan pada tahun sebelumnya yakni pada tahun 2012 masyarakat yang menggunakan jasa rentenir mencapai jumlah 300 orang pada desa Citeko dan 320 orang pada kelurahan Sindangsari. 
Tabel 11.Jumlah masyarakat yang menggunakan jasa rentenir pada desa Citeko dan Sindangsari.

\begin{tabular}{lcc}
\hline Periode & \multicolumn{2}{c}{ Desa/Kelurahan } \\
& Citeko & Sindangsari \\
\hline 2012 & 300 & 320 \\
2013 & 200 & 192 \\
\hline
\end{tabular}

Setelah jumlah masyarakat yang menggunakan jasa rentenir pada desa Citeko dan Sindangsari diketahui, maka fungsi tujuan dapat dirumuskan sebagai berikut:

MIN Z : $300 \mathrm{X}_{11}+200 \mathrm{X}_{12}+320 \mathrm{X}_{21}+192 \mathrm{X}_{22}$ Dengan formulasi kendala yang dapat dibentuk adalah :

a. Kendala modal BMT

Formulasi Kendala Modal BMT 199.200.000X $\mathrm{X}_{11}+249.000 .000 \mathrm{X}_{12} \leq$ 306.000 .000

$46.840 .000 \mathrm{X}_{21}+58.550 .000 \mathrm{X}_{22} \leq$ 306.000 .000

b. Kendala SDM BMT

Formulasi Kendala SDM BMT

$$
\begin{aligned}
& 1 X_{11}+1 X_{12} \leq 5 \\
& 1 X_{21}+1 X_{22} \leq 5
\end{aligned}
$$

c. Kendala sosialisasi

Formulasi Kendala Sosialisasi

$$
\begin{aligned}
& 1 X_{11}+1 X_{12} \leq 6 \\
& 1 X_{21}+1 X_{22} \leq 6
\end{aligned}
$$

d. Kendala dalam jangkauan BMT

Formulasi Kendala Jangkauan BMT

$3.780 .000 \mathrm{X}_{11}+4.500 .000 \mathrm{X}_{12} \leq 22.500 .000$

$3.780 .000 \mathrm{X}_{21}+4.500 .000 \mathrm{X}_{22} \leq 22.500 .000$

Jumlah masyarakat yang

menggunakan jasa rentenir di setiap desa selalu berubah-ubah dan menunjukkan bahwa setiap tahunnya mengalami penurunan.

Perbedaan kondisi seperti ini terjadi disebabkan salah satu faktornya adalah masyarakat sudah mulai paham dan sadar akan dampak Rentenir yang sangat berbahaya dan di desa juga sudah mulai banyak koperasi yang masuk, serta sudah ada dukungan pula dari Pemerintah melalui bantuan dana yang diberikan ke setiap desa berupa dana untuk masyarakat yang membutuhkan modal guna pengembangan usaha yakni program PNPM.

Setiap desa secara keseluruhan terdapat nilai reduced cost pada peubah $\mathrm{X}_{11}, \mathrm{X}_{12}, \mathrm{X}_{21}$, dan $\mathrm{X}_{22}$ hal ini menunjukkan bahwaBMT Berkah Mandiri Sejahtera dianjurkan bahwa kinerja BMT harus lebih ditingkatkan lagi karena jika tidak ditingkatkan maka tingkat masyarakat yang menggunakan jasa Rentenir tidak akan berkurang.

\section{Hasil Optimalisasi Sumber Daya}

Dalam hal ini, analisis dual memberikan penilaian terhadap sumber daya dengan melihat nilai slack/surplus dan nilai dual price. Slack/surplus sama dengan nol menunjukan bahwa sumber daya bersifat terbatas atau langka yang termasuk dalam sumber daya aktif. Nilai dual price merupakan nilai harga sumber daya yang menunjukkan besarnya pengaruh terhadap nilai fungsi tujuan, karena penambahan atau pengurangan pada nilai ruas kanan kendala. Nilai dual price pada sumber daya terbatas menunjukkan bahwa setiap penambahan sumber daya sebesar satu-satuan akan meningkatkan nilai fungsi tujuan sebesar nilai dual pricenya, sedangkan nilai dual price negatif pada sumber daya terbatas menunjukkan bahwa setiap penambahan sumber daya sebesar satu-satuan akan menurunkan nilai fungsi tujuan sebesarnilai dual price tersebut. Sumber daya dengan nilai dual price sama dengan nol menunjukkan bahwa sumber daya tersebut berstatus kendala tidak aktif atau berlebih, dimana penambahan atau pengurangan ketersediaan pada sumber daya tersebut tidak akan mempengaruhi nilai pada fungsi tujuan.

1) Penggunaan modal BMT

Penggunaan modal BMT Berkah Mandiri Sejahtera selama 2 periode (tahun 2012 dan 2013) pada kondisi optimal dapat dilihat pada tabel 4.40.Status penggunaan modal BMT Berkah Mandiri Sejahtera secara keseluruhan berstatus berlebih.Hal ini 
menunjukkan bahwa penggunaan ketersediaan modal BMT Berkah Mandiri Sejahtera belum dimanfaatkan sepenuhnya untuk penghapusan praktik rentenir. Artinya, BMT Berkah Mandiri Sejahtera belum memberikan pembiayaan yang optimal kepada desa Citeko dan kelurahan Sindangsari, karena berdasarkan data penelitian masih sedikit pembiayaan yang diberikan kepada desa Citeko dan kelurahan Sindangsari sedangkan jumlah masyarakat yang menggunakan jasa rentenir masih banyak. Seharusnya pembiayaan BMT Berkah Mandiri Sejahtera lebih diperbesar lagi untuk desa Citeko dan kelurahan Sindangsari ataupun pada desa-desa yang masyarakatnya masih banyak menggunakan jasa rentenir sehingga masyarakat yang masih menggunakan jasa rentenir menjadi beralih ke BMT Berkah Mandiri Sejahtera. Untuk itu, dalam hal ini meskipun ketersediaan modal BMT Berkah Mandiri Sejahtera ditambah, jumlah nasabah rentenir tidak akan berubah menjadi berkurang, karena nilai dual pricenya sama dengan 0 .

Tabel13 . HasilOptimalisasi Penggunaan Modal BMT.

\begin{tabular}{lrcc}
\hline Periode & $\begin{array}{r}\text { Slack / } \\
\text { Surplus }\end{array}$ & $\begin{array}{c}\text { Dual } \\
\text { Price }\end{array}$ & Status \\
\hline
\end{tabular}

$2012 \quad 306000000 \quad 0.000 \quad$ Berlebih

$2013 \quad 306000000 \quad 0.000$ Berlebih

1) Penggunaan SDM BMT

Faktor yang menyerap biaya besar pada BMT salah satunya adalah Sumber Daya Manusia.Penggunaan SDM pada BMT secara keseluuhan juga berstatus berebih.Hal ini menunjukkan bahwa ketersediaan SDM masih belum dimanfaatkan sepenuhnya untuk

Dalam menjalankan operasionalnya, BMT Berkah Mandiri Sejahtera menggunakan metode jemput bola.Metode ini menyerap biaya besar karena jangkauan BMT Berkah Mandiri Sejahtera sangat luas. Namun dalam penggunaan biaya transportasi BMT mengupayakan penghapusan praktik rentenir di masyarakat.Untuk itu, ketersediaan SDM pada BMT Berkah Mandiri Sejahtera tidak perlu ditambah, karena dengan SDM yang berjumlah saatini masih bisa meminimalisir jumlah praktik rentenir di masyarakat.Seharusnya kinerja SDM yang perlu ditambah dan menyusun strategi yang baik agar bisa meningkatkan jumlah nasabah BMT Berkah Mandiri Sejahtera, dengan hal itu masyarakat yang pernah menggunakan jasa rentenir jadi berpindah ke BMT Berkah Mandiri Sejahtera dan hal tersebut bisa mengurangi atau meminimalisir jumlah praktik rentenir di masyarakat.

Tabel 14.Hasil Optimalisasi Penggunaan SDM BMT

\begin{tabular}{rrrr} 
Periode & $\begin{array}{r}\text { Slack / } \\
\text { Surplus }\end{array}$ & $\begin{array}{r}\text { Dual } \\
\text { Price }\end{array}$ & Status \\
\hline 2012 & 5.000000 & 0.000000 & Berlebih \\
2013 & 5.000000 & 0.000000 & Berlebih \\
\hline
\end{tabular}

3) Penggunaan sosialisasi BMT

Sosialisasi yang dilakukan BMT Berkah Mandiri Sejahtera belum optimal pada tahun 2012 dan 2013.Hal ini ditunjukkan dengan status penggunaan sosialisasi yang masih berlebih.Artinyasosialisasi yang dilakukan oleh BMT Berkah Mandiri Sejahtera harus lebih dimanfaatkan lagi agar tujuan dalam meminimalisir praktik rentenir di masyarakat bisa tercapai.

Tabel 15.Hasil Optimalisasi Penggunaan Sosialisasi BMT

\begin{tabular}{rrrl}
\hline Periode & $\begin{array}{r}\text { Slack / } \\
\text { Surplus }\end{array}$ & $\begin{array}{r}\text { Dual } \\
\text { Price }\end{array}$ & Status \\
\hline 2012 & 6.000000 & 0.0 & Berlebih \\
2013 & 6.000000 & 0.0 & Berlebih \\
\hline
\end{tabular}

3) Penggunaan jangkauan BMT

Berkah MandiriSejahtera pada desa Citeko dan kelurahan Sindangsari masih berstatus berlebih, artinya ketersediaan biaya transportasi untuk desa Citeko dan kelurahan Sindangsari masih belum dimanfaatkan sepenuhnya dalam mengupayakan penghapusan praktik 
rentenir di masyarakat. Untuk itu, ketersediaan biaya transportasi tidak usah ditambah, karena nilai dual price nya secara keseluruhan masih bernilai 0 . Seharusnya BMT Berkah Mandiri Sejahtera meningkatkan kinerja SDM BMT Berkah Mandiri Sejahtera agar mendapatkan nasabah yang lebih banyak pada desa Citeko dan kelurahanSindangsari, sehingga masyarakat yang masih menggunakan jasa rentenir menjadi beralih menggunakan jasa BMT Berkah Mandiri Sejahtera yang kemudian biaya transportasi bisa dimanfaatkan sepenuhnya untuk metodejemput bola pada desa Citeko dan kelurahan Sindangsari.

Tabel 16.Hasil Optimalisasi Penggunaan Jangkauan BMT

\begin{tabular}{ccccc}
\hline Periode & $\begin{array}{c}\text { Slack / } \\
\text { Surplus }\end{array}$ & $\begin{array}{c}\text { Dual } \\
\text { Price }\end{array}$ & Status \\
\hline 2012 & 22500000 & & 0.0 & Berlebih \\
2013 & 22500000 & & 0.0 & Berlebih \\
\hline
\end{tabular}

\section{Analisis Sensitivitas}

Analisis sensitivitas diperlukan untuk mengetahui sejauh mana hasil optimal dapat diterapkan apabila terjadi perubahan terhadap model.Pengaruh perubahan dapat dilihat dari selang kepekaan yang terdiri dari batas minimum dan batasan maksimum.Batas minimum (allowable decrease) merupakan batas penurunan kendala yang tidak merubah model dan batas maksimum(allowable increase) merupakan batas kenaikan kendala yang tidak merubah model. Semakin sempit selang kepekaan yang dimiliki oleh suatu kendala, maka kendala tersebut akan semakin peka dalam membuat perubahanterhadap solusi optimal. Analisis sensitivitas terbagi menjadi dua, yaitu analisis sensitivitas nilai koefisien fungsi tujuan dan analisis sensitivitas ruas kanan kendala.

- Analisis sensitivitas nilai koefisien fungsi tujuan
Analisis sensitivitas nilai koefisien fungsi tujuan merupakan selang perubahan harga terhadap koefisien fungsi tujuan yang tidak mempengaruhi nilai optimal dari peubah, walaupun nilai optimum akan berubah sesuai dengan perubahan harga pada masing-masing peubah tersebut.

Tabel 17.Analisis Sensitivitas Nilai Koefisien Fungsi Tujuan

\begin{tabular}{cccc}
\hline Peubah & $\begin{array}{c}\text { Current } \\
\text { Coef. }\end{array}$ & $\begin{array}{c}\text { Allowable } \\
\text { Increase }\end{array}$ & $\begin{array}{c}\text { Allowable } \\
\text { Decrease }\end{array}$
\end{tabular}

$\begin{array}{llll}\text { X11 } & 300.000 & \text { INFINITY } & 300.000 \\ \text { X12 } & 200.000 & \text { INFINITY } & \text { ).000 } \\ \text { X21 } & 320.000 & \text { INFINITY } & \text { ).000 } \\ \text { X22 } & 192.000 & \text { INFINITY } & 2.000\end{array}$

Berdasarkan tabel diatas, dapat dilihat banyak peubah yang tidak memiliki batasan (infinity) dalam menaikan koefisien fungsi tujuan, akan tetapi memiliki batasan dalam menurunkan koefisien fungsi tujuannya. Nilai masingmasing batasan berbeda untuk setiap peubah.Sebagai contoh, peubah $\mathrm{X}_{11}$ tidak memiliki batasan dalam menaikkan koefisiennya dan memiliki batasan dalam menurunkan koefisien sejumlah 300 orang.

- Analisis sensitifitas nilai ruas kanan kendala

Analisis sensitivitas nilai ruas kanan kendala menunjukkan selang perubahan pada ketersediaan sumber daya yang tidak akan menyebabkan nilai dual berubah. Semakin sempit selang kepekaan suatu sumber daya, berarti sumber daya tersebut semakin peka terhadap perubahan nilai ruas kanan kendalanya.Batas perubahan yang terjadi pada kendala-kendala yang menjadi pembatas peran BMT setiap periodenya.Untuk kendala-kendala yang berstatus berlebih, pada analisis sensitivitas nilai ruas kanan kendala memiliki nilai peningkatan yang tak terbatas.Sedangkan untuk kendalakendala yang berstatus langka memiliki 
nilai batas penggunaan untuk penambahan atau pengurangan sumber daya sampai batas tertentu.

Selang kepekaan ketersediaan modal dapat dilihat pada tabel dibawah ini.Pada kolom (1), menunjukkan kendala modal dimulai dari M01-M02.Kolom (2), menunjukkan ketersediaan modal BMT.Sedangkan kolom (3) dan (4), menunjukkan selang dari ketersediaan modal yang dapat diterima model.Untuk ketersediaan modal, batasan kenaikan (allowable increase) yang dapat diterima model menunjukkan batas tak hingga dan batas berhingga.

Tabel 18.Selang kepekaan

ketersediaanmodal BMT

\begin{tabular}{llll}
\hline Row & $\begin{array}{l}\text { Current } \\
\text { RHS }\end{array}$ & $\begin{array}{l}\text { Alloable } \\
\text { Increase }\end{array}$ & $\begin{array}{l}\text { Allowable } \\
\text { Decrease }\end{array}$ \\
\hline M01 & 6000000 & INFINITY & 306000 \\
M02 & 6000000 & INFINITY & 306000 \\
\hline
\end{tabular}

Batas tak hingga berarti persediaan modal berlebih.Sedangkan batas berhingga menunjukkan adanya batas peningkatan sampai nilai tertentu (sesuai nilai pada tabel).Berdasarkan Tabel diatas, menunjukkan bahwa terdapat batas peningkatan tak hingga pada model. Untuk itu tidak ada gunanya menambah penggunaan modal, karena sebenarnyamodal untuk mengatasi masyarakat yang menggunakan jasa Rentenir masih berlebih,artinya banyak modal yang belum dialokasikan untuk menangani masyarakat yang menggunakan jasa Renteniragar minimalisasi praktik Rentenir di masyarakat bisa tercapai.Batasan pengurangan penggunaan modal sebesar Rp. 306.000.000.

Tabel 19.Selang kepekaan ketersediaan SDM BMT

\begin{tabular}{llll}
\hline M & $\begin{array}{l}\text { Current } \\
\text { RHS }\end{array}$ & $\begin{array}{l}\text { Allowable } \\
\text { Increase }\end{array}$ & $\begin{array}{l}\text { Allowable } \\
\text { decrease }\end{array}$ \\
\hline D01 & 5000000 & INFINTY & 5000000
\end{tabular}

D02 $5000000 \quad$ INFINTY 5000000

Berdasarkan Tabel diatas, menunjukkan bahwa terdapat batas peningkatan tak hingga pada model. Untuk itu tidak ada gunanya menambah penggunaan SDM pada BMT dalam meminimalisir praktik Rentenir di masyarakat, karena sebenarnya SDM yangada pada BMT saat ini mengalami kelebihan,artinya SDM BMT belum memanfaatkan secara optimal dalam menjalankan perannya sebagai penghapus praktik ribawi di masyarakat. Dengan jumlah SDM BMT saat ini, BMT masih bisa mengatasi atau berperan dalammeminimalisir praktik Rentenir di masyarakat.Batasan pengurangan penggunaan SDM sebesar 5 Orang .

Tabel 20. Selang kepekaan ketersediaan sosialisasi BMT

\begin{tabular}{llll}
\hline Row & $\begin{array}{l}\text { Current } \\
\text { RHS }\end{array}$ & $\begin{array}{l}\text { Alloable } \\
\text { Increase }\end{array}$ & $\begin{array}{l}\text { Allowable } \\
\text { Decrease }\end{array}$ \\
\hline S01 & 6000000 & INFINITY & 6000000 \\
S02 & 6000000 & INFINITY & 6000000 \\
\hline
\end{tabular}

Berdasarkan Tabel diatas, menunjukkan bahwa terdapat batas peningkatan tak hingga pada model.Batasan pengurangan sosialisasi pada BMT sebesar 6 kali.Artinya BMT BerkahMandiri Sejahtera harus lebih meningkatkan sosialisasi di masyarakat agar jumlah praktik Rentenir di masyarakat berkurang.

Tabel 21.Selang kepekaan ketersediaan jangkauan BMT

\begin{tabular}{llll}
\hline Row & $\begin{array}{l}\text { Current } \\
\text { RHS }\end{array}$ & $\begin{array}{l}\text { Alloable } \\
\text { Increase }\end{array}$ & $\begin{array}{l}\text { Allowable } \\
\text { Decrease }\end{array}$ \\
\hline S01 & 22500000 & INFINITY & 22500000 \\
S02 & 22500000 & INFINITY & 22500000 \\
\hline
\end{tabular}

Berdasarkan Tabel diatas, menunjukkan bahwa terdapat batas peningkatan tak hingga pada model.Untuk itu tidak ada gunanya menambah biaya 
transportasi, karena sebenarnya biaya transportasi mengalami kelebihan, artinya BMT harus menambah kinerja agar nasabah BMTberkurang dan pemakaian biaya transportasi menjadi banyak yang dimanfaatkan.Batasan pengurangan penggunaan biaya transportasi sebesar Rp. 22.500.000.

\section{KESIMPULAN DAN IMPLIKASI}

Masyarakat sampai hari ini masih menggunakan jasa Rentenir dalam memenuhi kebutuhannya, baik berupa modal maupun konsumtif.Namun saat ini jumlah masyarakat yang menggunakan jasa Rentenir sudah sedikit berkurang. Hal ini terbukti bahwa pada tahun 2012 pengguna jasa Rentenir di desa Citeko berjumlah 300 orang, namun pada tahun 2013 kini jumlahnya sudah berkurang menjadi 200 orang.

Peran BMT dalam menjalankan fungsinya sebagai Lembaga Keuangan Mikro Syariah yang membebaskan masyarakat dari ekonomi ribawi telah menunjukkanperannya kepada masyarakat. Jika BMT Amal Atina melalui penyampaian program ekonomi syariah melalui sosialisasi kepada masyarakat, memberikan pemahaman secara langsung kepada masyarakat melalui pemberian pembiayaan secara syariah, serta membentuk gerakan BMT melalui majelis keluarga utama. Sedangkan upaya yang dilakukan BMT Berkah Mandiri Sejahtera melaui pendekatan dengan nilai-nilai akidah dan akhlak kepada masyarakat, kemudian pendekatan dengan tokoh masyarakat, memberikan kemudahan dalam memberikan pembiayaan kepada masyarakat, serta memperbanyakkelompok-kelompok muamalah ataujama'ah di komunitas pedagang.

Diharapkan kepada pengelola BMT agar lebih fokus untuk berperan memerangi praktik Rentenir di masyarakat, karena hasil meminimalisir praktik Rentenir di masyarakat belum mencapai hasil yang optimal. BMT akan lebih efektif, apabila kinerja BMT lebih ditingkatkan lagi untuk memerangi praktik Rentenir di masyarakat, sehingga tujuanuntuk meminimalisir praktik rentenir dapat dicapai secara optimal oleh BMT, Jika BMT memiliki kendala seperti kekurangan modal, BMT yang sudah terdaftar di ABSINDO (Asosisasi BMT SeIndonesia) bisa meminta bantuan kepada ABSINDO atau pada BMT lain yang yang telah terdaftar pada ABSINDO dan memiliki kelebihan dana.

\section{DAFTAR PUSTAKA}

Achmadi, Indra. Optimalisasi.Diakses dari indraachmadi.blogspot.com pada tanggal 30 Desember 2013.

Alma, Buchari. Donni Juni Priansa. 2009. Manajemen Bisnis Syariah. Bandung:Alfabeta.

Anonim. Macam-macam Teknik Pengambilan Sampel.Diakses dari expresisastra.blogspot.compada tanggal 21 Januari 2014.

Arifin, Zainul. Dasar-Dasar Manajemen Bank Syariah. Jakarta:Alvabet.

Coy, Tholhah. Peran Lembaga Dan Kader Pemberdayaan Masyarakat Desa.Diakses dari tholhahcoy.blogspot.compada tanggal 30 Desember 2013.

Hariyati, Ninik, SS. 2010. Tesis:Peran Bank Syariah dalam Mengoptimalkan UMKM Kota Yogyakarta. Yogyakarta:UIN Sunan Kalijaga.

Ilham, Muhammad. 2008. Skripsi:Peran Dewan Pengawas Syariah terhadap Lembaga Keuangan Islam Non Bank dalam Mendorong Pembiayaan untuk Sektor Usaha Kecil dan Menengah (Studi Kasus BMT Amal Atina Bogor). Bogor:Fakultas Studi Islam Universitas Djuanda.

Latifah, Rikawati Kurnia. 2011. Optimalisasi Penggunaan Faktor-Faktor Produksi Peternakan Ayam Ras Pedaging (Studi Kasus:Kandang Holil Soma Unggas Farm Bogor). Bogor:Institut Pertanian Bogor. 
Lubis, Suhrawardi K. 2000. Hukum Ekonomi Islam. Jakarta: Sinar Grafika.

Nasrul, Nurul. 2009. Optimalisasi Produksi Nata De Coco Mentah pada PD Risna Sari Kabupaten Cianjur Provinsi Jawa Barat. Bogor:Institut Pertanian Bogor.

Nedri, Davy H. Dampak rentenir terhadap pedagang pasar tradisional.Diakses dari docstoc.com pada tanggal 3 Oktober 2013.

Nugraha, Rahmat, dkk. 2011. PKM:Strategi Optimalisasi BMT berbasis Masjid sebagai solusi asimetri informasi untuk membangun sektor pertanian dengan karakter kewirausahaan. Bogor:Institut Pertanian Bogor.

Nurhaeni, Siti. 2009. Skripsi:Strategi Pengembangan Organisasi Baitul Maal Wa Tamwil (BMT). Yogyakarta:Universitas Islam Negeri Sunan Kalijaga.

Purba, Roberto. 70\% UMKM di Jabar terjerat rentenir dalam kabar ekonomi

Rahmawati. 2001. Skripsi:Manajemen Operasional Bank Keliling di Kelurahan Pakansari Kecamatan Cibinong-Bogor. Bogor:Fakultas Studi Islam Universitas Djuanda.

Rohmatika, Roya. Baitul maal wat tamwil.Diakses dari royarohmatika.blogspot.com pada tanggal 3 Oktober 2013.

Rozalinda. 2012. Fenomena Rentenir Di Kota Padang Studi Analisis Peranan Baitul Mal Wa Tamwil (BMT) Taqwa Muhammadiyah dalam Membebaskan Masyarakat dari Rentenir. Padang:IAIN Imam Bonjol Padang.

Sudarsono, Heri. 2008. Bank dan Lembaga Keuangan Syariah. Yogyakarta: Ekonisia.

Syaifullah, Muhammad. Aset BMT Tumbuh Signifikan.Diakses darihttp://www.tempo.com pada tanggal 08 November 2012.

Yuli, Cantika. Peran Baitul Maal Wa Tamwil (BMT) Dalam Pemberdayaan Usaha Mikro, Kecil dan Menengah (UMKM). Diakses dari kompasiana.com pada tanggal 24 Januari 2013.

Yunus, Jamal Lulail. 2009. Manajemen Bank Syari'ah. Malang: UIN-Malang Press. 